\title{
Reducing the Outflow of CBRN Soldiers from the Perspective of Motivation
}

\author{
Attila CSÓKA $^{1 \oplus}$
}

\begin{abstract}
Outflow itself and the turnover of personnel are natural phenomena and occur in any organisation. The motivational factors influencing outflow can be classified as financial, medical and psychological factors. Compared with the two other factors, the psychological factor is the most complex one. In the research, the author examined these psychological factors among the soldiers of the HDF $93^{\text {rd }}$ CBRN Battalion in 2008 and in 2018 and compared the differences. The author also analysed the relationship between salary-motivated outflow and age, defining a key amount that should be taken into consideration in order to prevent the mass outflow.
\end{abstract}

Keywords: outflow, motivation, CBRN soldiers, psychological factors

The outflow and turnover of personnel is a natural phenomenon in any military organisation and results in the loss of personnel, expertise, knowledge and experience. Replacement of the lost person with a trained one takes a long time.

We have to examine what motivates soldiers' decisions when their contract expires. I will mention the financial factor although, in contrast with the motivational factors, it cannot be changed without investing a significant amount of money.

Contract servicemen and women join up voluntarily. The cohesion of the unit, the camaraderie and teamwork are more and more important. Over a long time in service, good personal relationships can be built both on duty and off duty - even with family members. These good relationships enhance the cohesion of the subunit.

\section{Training system}

A CBRN subunit that is able to execute the orders of its commander with a high level of professionalism requires long and complex specialised training. The summary of a training cycle is as follows.

First, the civilian applicant has to decide whether he/she wants to join up or not. If the answer is yes, and the application form has been filled in and handed over, the applicant is

PhD student, University of Public Service Doctoral School of Military Sciences; e-mail: csoka.attila@yahoo. com 
sent for a medical examination and a psychological assessment to establish whether he/she is suitable for military service.

If the applicant is found suitable, he/she is issued with equipment and completes basic training, where he/she learns the basic military skills.

Specialised training follows basic training. ${ }^{2}$ During this training, soldiers acquire the theoretical and practical knowledge that is necessary for their daily work.

After basic training, the new CBRN soldiers know how to use their individual protective equipment and they have basic theoretical knowledge of weapons of mass destruction.

As the first step of their specialised training for their planned assignment, they attend lectures on the CBRN reconnaissance and decontamination equipment that are available in the CBRN battalion. Using this equipment comes with huge responsibility and requires profound knowledge because it includes, for example, the HAPSITE ER person-portable Gas Chromatograph/Mass Spectrometer, the remote chemical reconnaissance equipment and the Decontamination Container, which in this order respectively cost approximately 250 times, 400 times and 1,200 times more than their monthly salary.

The next step is the acquisition of squad-level CBRN tactics in a tactical situation, cooperating with the other members of the squad while following the squad leader's orders.

During the discussion of platoon level training, which is the next step, we have to discuss separately the areas of CBRN reconnaissance and CBRN decontamination. The specialised CBRN work in a decontamination station - set up by a decontamination platoon - is led by the platoon leader. The platoon leader sets up his/her mobile command post in the area of the decontamination station and is able to check directly the execution of his/her orders. CBRN decontamination requires teamwork, so in case of facing problems, the individual has the possibility to ask for help from several levels: his/her teammates, the squad leader and even the platoon leader, following the chain of command.

Self-sufficiency is a requirement for CBRN reconnaissance soldiers. They work separately from the platoon leader and, depending on the task organisation, one or two CBRN operators handle the CBRN reconnaissance devices.

The complexity of their task does not make it acceptable for the CBRN reconnaissance soldier and the driver of the APC, who also needs to know the procedures and be able to handle the assets, to be uncertain in the performance of their specialised task.

One of the basic missions of CBRN soldiers is to take part in the Defence Disaster Management System and therefore they must be prepared by training in consequence management after a nuclear accident, and by training in aerial radiological survey. ${ }^{3}$ After training courses and exercises at home, CBRN specialists receive international individual training using live chemical warfare agents followed by squad and platoon level training.

Ideally, at the end of the specialised training, the soldier is ready to act with full effectiveness, but in reality, this never happens. They need to turn the theoretical knowledge into practical skills, they need to practise every part of their task in every

MH 93. Petőfi Sándor Vegyivédelmi Zászlóalj 2019. évi munkaterve [213/2019 HDF 93d CBRN BN Work Programme for 2019].

3 MH 93. Petőfi Sándor Vegyivédelmi Zászlóalj Katasztrófavédelmi Alkalmazási Terv [4/853 HDF 93 ${ }^{\text {rd }}$ CBRN BN Disaster Management Response Plan]. 
season several times, working together with other soldiers and they need to understand the orders of the squad/platoon leader. This process enables the subunit to accomplish its task without any complication.

The acquired knowledge and experience make the soldier capable of conducting real CBRN tasks both in Hungary and abroad. The training cycle takes approximately 18 months.

In order to be able to meet national interests and international commitments, the outflow of soldiers must be minimised.

\section{Outflow and the factors affecting it}

Outflow itself and the turnover of personnel are natural phenomena and occur in any organisation. Both unmotivated and medically unsuitable persons leave the system, as well as soldiers who feel there is more opportunity in the civilian sector.

Attrition results in the following three types of deficiency:

- His/her appointment becomes vacant and those who remain have to work more and consequently become overburdened.

- The leaving soldier takes his/her knowledge, expertise and experience with him/her. It takes a long time for his/her replacement to acquire the same knowledge on the job.

- A member of a cohesive unit leaves and it takes time for a new soldier to build similarly deep relationships.

In most of the cases, soldiers do not terminate their existing contract but those whose contract has expired do not sign up again. An old soldier has influence on the others. If there are soldiers whose contracts expire at the same time and there is at least one among them who wants to leave, then that soldier usually tries to persuade the others to do the same.

I also saw this kind of behaviour while on an operational tour in Iraq. A CBRN soldier who had been injured by an IED was about to be repatriated and he tried to persuade the others to terminate their tour.

In the background of this behaviour, there is a human feeling: doubt. The soldier is not sure about leaving and would like to find reassurance and the confirmation of his/ her intention in the decision of the persuaded mate. He/she does not want to go through the process of secession from the organisation and the camaraderie alone. Therefore, sometimes in a subunit there is a surge of soldiers who want to quit, enhancing the above mentioned 3 negative effects of attrition. In a unit that requires special training - like CBRN units - these negative effects have severe consequences.

However, new soldiers bring their own perspectives and new ideas, which sometimes have a good effect on the subunit. If an unmotivated soldier is replaced by an ambitious and motivated newcomer, the turnover will be beneficial to some extent. The impact of the 'new blood' is much more important if it is injected in the chain of command, where the new approach is complemented with the possibility to act. 
Based on the above, we can say that turnover, decreased to the level where there is a place for ambitious newcomers and the outflow of unmotivated soldiers causes neither professional nor emotional crisis in the life of even one CBRN subunit, is a precondition of the effective functioning of any organisation.

Outflow can be reduced by creating conditions, which make the soldier stay. If the soldier loses his/her interest in leaving, if he/she is motivated to stay and to sign up again, we are close to the solution of the problem.

The motivational factors influencing outflow can be classified as:

- financial

- medical

- psychological factors

They will be discussed below.

\section{Financial factors}

Practically, the most important factor is the salary and other financial allowances. Everyone needs money, everyone has to pay the bills and support their family. If a job is well paid, the importance of the other factors may decrease.

Since the financial resources of the armed forces are not infinite and the allowances are limited, it is necessary to place emphasis on the other factors.

A possible way of financial motivation is the possibility to do operational tours of duty abroad, where the reward of the more dangerous task and being away from the family is the higher salary.

\section{Medical factors}

Commanders and subunit leaders do not have the power to change or affect the medical motivational factor. This factor can be seen as an 'only negative' factor.

The ability to pass the physical and medical tests in itself is not enough motivation for a soldier to sign a new contract. On the other hand, if the health of the soldier deteriorates and he/she finds it hard to pass or is unable to pass the tests and/or is not able to wear the individual protective equipment, after a while he/she will have to be discharged.

If the soldier involved is a respected member of the unit or he/she got injured while carrying out his/her duty, the medical factor can become a psychological factor in case of the others, having an increased negative psychological effect on them: they may see their own possible future and think the same may happen to them. 


\section{Psychological factors}

Compared with the two other factors, the psychological factor is the most complex one. There is no pattern that applies to each and every soldier in any situation. In my research, I examined these psychological factors among the soldiers of the HDF 93 ${ }^{\text {rd }}$ CBRN Battalion in 2008 and 2018. They were asked what factors other than the financial and medical factors (due to their unchangeable nature) motivated their decisions to sign up again or to sign off. When I compared the findings of the two surveys, I realised that over these 10 years, their opinions changed.

In 2008, the following six factors were mentioned:

- soldier-to-soldier relations

- commander-to-subordinate relations

- social recognition

- elite consciousness

- physical training

- professional recognition

- courses

- successful community

- career

- rank and promotion

- transition from NCO to officer

- transition from contract to career status

- maximisation of the length of contractual service

Since the maximisation of the length of contractual military service was rescinded, this factor could not be included in the 2018 survey and it was replaced by questions about the effect of being within their comfort zone.

Some factors include several components but because of their relatedness they can be dealt with together.

\section{Soldier-to-soldier relations}

The atmosphere and personal relations play an important role in the functioning and the effectiveness of a subunit.

The lack of good camaraderie is an impediment to mission execution and damages efficiency and effectiveness. A bad atmosphere can lead to insubordination, making it difficult for the commander to lead the unit and consequently undermining commanderto-soldier relations.

In case of a good atmosphere, the soldiers feel responsible for each other. They do their work well, knowing that if they do not, the others will have to do it. If a problem occurs, they willingly try to solve it among themselves. It is common for them and even for their families to meet after working hours. 
If the atmosphere is good, a soldier whose contract is about to expire will take into account the loss of these relationships.

Both the soldiers themselves and the subunit commander are responsible for creating good soldier-to-soldier relations. If the commander does not show favouritism, if everyone takes part in both the popular and the unpopular tasks, if the commander 'takes care' of undisciplined soldiers, then he/she protects the unit from avoidable sources of conflict.

\section{Commander-to-subordinate relations}

Commander-to-subordinate relations are determined by the commander's leadership style.

Leadership psychology and leadership theory literature discusses the various styles of leadership and among others mentions the autocratic, democratic and laissez faire styles identified by Lewin, ${ }^{4}$ the Tannenbaum-Schmidt Leadership Continuum and BlakeMouton's ${ }^{5}$ or Fiedler's person-centred models. ${ }^{6}$

There are four extreme styles of leadership:

1. The commander's leadership style is consistent and dogmatic. He rarely or never accepts the suggestions of his/her subordinates. The subunit is under continuous control through the platoon and squad leaders. The tasks of the subunit are always accomplished. The soldiers know what to expect, there is no uncertainty and everyone knows what to do. Under the command of this kind of leader, soldiers may still feel that they miss something because their well-being and needs are pushed into the background.

2. The commander is a consistent and strong-handed leader, but also listens to the soldiers' suggestions and pays attention to their problems. The soldiers can work under predictable conditions and at the same time, their well-being is also looked after.

3. The commander is primarily concerned with the well-being of the soldiers and maintains friendly relations with them even at the cost of task accomplishment and effectiveness. This kind of commander will sooner or later lose the respect of his/her subordinates and the recognition of his/her superiors due to the inadequate quality of their work. Typically, the soldiers will become unmanageable.

4. The 'commander' has no interest either in the task or the well-being of his/her subordinates. He/she is only interested in his/her own comfort. The soldiers do not know what they are supposed to do, and they are even likely to become aggressive.

The list above includes the four most extreme leadership styles. The last two styles do not work in an organisation where the chain of command is rigorously followed. In reality,

$4 \quad$ Katalin Fehér, 'Nevelési stílusok', s. a.

5 András Karácsonyi, A leadership, a szervezeti kultúra és kapcsolatuk jellegzetességei a magyar szervezetek esetében (PhD thesis, Corvinus University of Budapest, 2006), 17, 19.

$6 \quad$ Eryn Travis, 'Fiedler’s Contingency Theory of Leadership', Bizfluent, 02 November 2018. 
there is no commander with only one typical leadership style. They usually carry a mix of different styles and fall between the extremes.

Apparently, the difference between two commanders depends on how much each of the above styles characterises their behaviour.

In the long-term, soldiers appreciate the consistent and caring leadership style out of the 4 styles. In the short term, it is convenient for the soldiers to have a friendly but unmotivated 'leader', but after a while due to the accumulation of unaccomplished tasks, the commander and the whole unit will be disgraced. Last but not least, a leader unworthy of the respect of his/her subordinates is repugnant in the eyes of some soldiers.

\section{Social recognition}

When people talk about what their job is, it does matter a lot how they talk about it. Are they proud of their work or are they ashamed of it?

If the social recognition of the military career is high in any country, then there is no lack of new recruits, and serving soldiers think twice before leaving the service.

Being appreciated as a soldier is a fragile status. World politics can change the opinion of the civilians. Taking part in a dangerous mission and doing a good job has a positive effect on social recognition, while the same activity can negatively affect it in case of well-organised counterpropaganda.

During peacetime and when no disasters happen, many civilians regard the armed forces as a waste of money. In order for society to appreciate the military more, in my opinion, soldiers should have a much stricter work routine than ordinary people, who have a 9 to 5 job. In case of a natural or industrial disaster, the activity of the soldiers is welcomed by the public. For example, after the red sludge disaster in 2010, CBRN soldiers worked in the affected area conducting road clearance and vehicle operational decontamination for 3 months, during which time more than 31,000 vehicles ${ }^{7}$ were washed down by CBRN soldiers.

If PT were done early every morning, every subunit would be able to conduct its specialised training during working hours without the pressure to try to include physical training in their daily schedule. If the behaviour of the soldiers was exemplary, it would result in a positive change in the public perception of the military. If the soldiers rigorously adhered to the military regulations while they wore the uniform, it would be a great leap forward in any armed forces. If their off-duty lifestyle served as a pattern, it would help the military gain higher social recognition.

Zoltán Szombati and László Földi, ‘Az MH 93. Petőfi Sándor Vegyivédelmi Zászlóalj katasztrófa-elhárítási feladatban való részvételének tapasztalatai’, Hadmérnök 6, no 1 (2011), 254. 


\section{Elite consciousness}

Elite consciousness, to my mind, is the consciousness of being highly qualified to do one's job, which is the self-confidence that soldiers have when they know that they are good at what they are doing, when they can answer any CBRN-related question, they can solve most of the technical problems and their mental and physical condition is better than that of an average civilian.

Obviously, people enjoy doing what they are good at. They know that they are capable of overcoming the difficulties and meeting the challenges and they regularly have a sense of achievement from their work.

In addition, completing other military courses and training (CBRN EOD, SO CBRN, and so on) enriches soldiers' professional knowledge and enhances their elite consciousness.

Elite consciousness has four components:

- professional recognition

- physical training

- courses

- successful community

\section{Professional recognition}

If workers do their jobs well, they need to be praised. If soldiers have learned their trade well and they are able to accomplish their tasks, their superiors have to find a way to recognise their accomplishments.

It is extremely important to give soldiers military tasks and only on very rare occasions other supplementary tasks like cleaning barracks or weeding the parade ground, which decreases their motivation and is both a waste of their time and a waste of their special CBRN knowledge that they acquired at the expense of the armed forces. A rocket scientist should not be made to dust the rocket and similarly a trained CBRN decontamination/ reconnaissance soldier should not be made to weed the parade ground.

Challenge is needed to maintain the interest of the soldiers on the required level. They did not join the armed forces to get bored. Every branch in the armed forces should establish norms and set requirements to measure the performance of the soldiers. In the same way as paratroopers are awarded different levels of jump wings based on the number and type of jumps they have completed, a method should be worked out to recognise accomplishments in every area of military life. The performance of CBRN soldiers could be recognised by awarding badges ( $1^{\text {st }}$ class, $2^{\text {nd }}$ class, $3^{\text {rd }}$ class CBRN decontamination/ reconnaissance soldier).

In my opinion, wearing the badge of achievement on the uniform would enhance soldiers' pride in their work and elite consciousness. 


\section{Physical training (PT)}

Ranking the soldiers based on the result of their PT test has a positive effect on their elite consciousness or their desire to prove themselves. I disagree with the conclusion that being ranked in the bottom tier would lead to soldiers losing their motivation. On the contrary: since there is a healthy level of rivalry among service members, it would actually motivate soldiers to make more effort and do better.

PT improves the physical, medical and mental condition of the soldiers and facilitates unit cohesion. Good physical condition is a prerequisite to wearing the CBRN individual protective equipment while doing time-consuming CBRN reconnaissance and decontamination tasks.

In my opinion, as discussed above, a daily early-morning PT - even including a unit/ subunit run in a civilian area - would improve the social recognition of the military.

\section{Courses}

After graduation from a course, soldiers should be awarded a badge. Wearing this badge on the uniform would have a double effect: everyone would know what qualifications the soldier has and it would make it possible for the wearer to inform others about who they are, which, in turn, would enhance their pride.

\section{Successful community}

The result of good soldier-to-soldier relations is a collaborative community. If the members of this community are highly trained and have a good leader, every accomplishment will be perceived as the collective success of the subunit, improving the atmosphere and both the commander-to-soldier and the soldier-to-soldier relations.

Sports competitions between subunits can be sources of success. For example, winning a soccer cup can make the feeling of togetherness stronger and can be a positive experience for every member of the subunit, even for those who were not on the team.

\section{Career}

\section{Rank and promotion}

Career and rank have almost the same importance for contract and career NCOs and officers, and it should be understood correctly. Promotion to the next rank without merit within a short period of time will lead to the rank losing its value and becoming a mere mode of address, an empty title without any content at all. If soldiers need to work for the 
next rank and earn it through several years of service, work and experience, the value of the rank will be preserved. A soldier with a lower rank respects it, knowing it was earned. If it takes longer for a soldier to be promoted to the next rank, it will never happen that two soldiers - one with two years and the other twelve years in service - have the same rank.

\section{Transition from NCO to officer}

There is a logical connection between rank/promotion and transition from NCO to officer. Soldiers need the opportunity to be promoted to a higher rank and be given a higher military appointment if they earn it through their abilities and good performance at work.

Choosing and grooming the new subunit leaders from among the suitable serving soldiers is a good and effective method. If the method of selection is appropriate, the new leader knows the abilities of his/her subordinates and the subordinates, his/her former buddies, also know and respect the leader.

The respect and acknowledgement of the subordinates are not automatic accompaniments of the stars on the rank insignia but have to be earned.

With this method, leadership positions will be filled by the right person and everyone will have the chance to achieve a higher rank and get a higher appointment and consequently transition from NCO to officer.

\section{Transition from contract to career status}

Career status provides more opportunities and more advantages to any soldier than contract status. One of the important advantages is the housing lease support, which is available for entitled career personnel. However, the most important advantage in 2008 was that the length of service for career military personnel was not limited to 15 years, which was the maximum length of service for contract personnel. Career service members could stay in the military until retirement.

\section{Maximisation of the length of contractual service}

This regulation was a very important negative motivating factor. Even for young career entrants without experience it is not easy to find a job in the civilian sector. For a 40-yearold contract soldier with fifteen years in service who cannot extend his/her contract due to this regulation, it is almost impossible to find a civilian job even if he/she has civilian qualifications but no actual job experience.

In 2018, this limitation was not in effect anymore, that is why in 2018 this factor was replaced by the zone of comfort. 


\section{The zone of comfort}

It is the result of a well-functioning daily routine. The comfortable sense of the predictability of the coming days, weeks and months in the company of well-known colleagues and of not having to meet new challenges.

\section{The importance of the psychological factors}

A survey was made among 50 contract soldiers from the HDF $93^{\text {rd }} \mathrm{CBRN}$ Battalion on the importance of the psychological motivating factors discussed above. Respondents were asked to rank the psychological motivating factors affecting their decision when their contract is up from very important to not relevant ( 1 = very important, $6=$ not relevant). Table 1 shows the result of the 2008 questionnaire: the number of soldiers ranking the factors as 1, 2, 3, 4, 5 and 6 for importance in their decision-making. The survey was anonymous.

Table 1: The importance of motivating factors in 2008

\begin{tabular}{|c|c|c|c|c|c|c|c|}
\hline & \multicolumn{6}{|c|}{ Importance } & \multirow[b]{2}{*}{$\sum$} \\
\hline & 1 & 2 & 3 & 4 & 5 & 6 & \\
\hline $\begin{array}{l}\text { Maximisation of the length of } \\
\text { contractual service }\end{array}$ & $30 \times 1$ & $4 \times 2$ & $4 \times 3$ & $9 \times 4$ & $2 \times 5$ & $1 \times 6$ & 102 \\
\hline Commander-to-soldier relations & 10 & 14 & 20 & 4 & 2 & 0 & 124 \\
\hline Career & 4 & 24 & 4 & 8 & 4 & 6 & 152 \\
\hline Soldier-to-soldier relations & 4 & 6 & 18 & 13 & 2 & 7 & 174 \\
\hline Elite consciousness & 2 & 1 & 2 & 10 & 14 & 21 & 246 \\
\hline Social recognition & 0 & 1 & 2 & 6 & 26 & 15 & 252 \\
\hline
\end{tabular}

Source: Compiled by the author.

The result of the 2008 survey shows that the most important factor for the soldiers was the maximisation of the length of service, because of which most of the soldiers considered military service as a temporary way to earn money and intended to leave the army before they became too old to find a job in the civilian sector. Fortunately, this factor does not matter anymore since the maximisation of the length of contractual service has been rescinded.

Commander-to-soldier relations were more important than career because these relations determined their daily work. However, career was more important than soldierto-soldier relations, which confirmed the appropriateness of the new practice of selecting squad leaders from among the soldiers.

Elite consciousness was ranked at the bottom, which can be explained by the lack of an evaluation system. Elite consciousness has a positive effect only if it exists. If it does not, there is no fear of losing it.

Social recognition was ranked 6 , due to the neutral perception of the military career. If there was a shift in the public perception of the military in either direction (positive 
or negative), it would have a motivating effect. If society respected the military, this effect would be positive, and if society despised soldiers, it would have a negative effect. Consequently, the factor would be viewed as more important.

Table 2 shows the result of the 2018 questionnaire in the same manner and Table 3 compares the results of the two surveys.

Table 2: The importance of motivating factors in 2018

\begin{tabular}{|c|c|c|c|c|c|c|c|}
\hline & \multicolumn{6}{|c|}{ Importance } & \\
\hline & 1 & 2 & 3 & 4 & 5 & 6 & $\sum$ \\
\hline Soldier-to-soldier relations & 22 & 14 & 8 & 3 & 2 & 0 & 101 \\
\hline Cmdr-to-soldier relations & 17 & 18 & 7 & 3 & 3 & 2 & 115 \\
\hline Elite consciousness & 2 & 6 & 11 & 10 & 15 & 6 & 198 \\
\hline Career & 4 & 2 & 9 & 15 & 11 & 9 & 204 \\
\hline Zone of comfort & 5 & 7 & 6 & 6 & 9 & 17 & 208 \\
\hline Social recognition & 0 & 3 & 9 & 13 & 11 & 14 & 224 \\
\hline
\end{tabular}

Source: Compiled by the author.

Table 3: Comparison of the results of the two surveys

\begin{tabular}{|l|c|c|}
\hline & $\mathbf{2 0 0 8}$ & $\mathbf{2 0 1 8}$ \\
\hline Cmdr-to-soldier relations & 124 & 115 \\
\hline Soldier-to-soldier relations & 174 & 101 \\
\hline Social recognition & 252 & 224 \\
\hline Elite consciousness & 246 & 198 \\
\hline Career & 152 & 204 \\
\hline Maximisation of the length of contractual service & 102 & - \\
\hline Zone of comfort & - & 208 \\
\hline
\end{tabular}

Source: Compiled by the author.

The fact that only one of the 50 soldiers in the 2018 survey was also a respondent in 2008 is proof of the high outflow of soldiers. Their attitude over the years changed.

Elite consciousness became more important. New equipment, service in the NATO Response Force and multinational training opportunities are signs of the enhanced CBRN life, which could cause an increased self-confidence. This is the road that we have to follow.

Despite the increasing self-confidence, the career factor lost its importance even though it was still ranked $4^{\text {th }}$ in the 2018 survey. Selecting the good leaders from the soldiers and the possibility to select the leaders from among the soldiers and to appoint them squad leaders was a new procedure in 2008 and many soldiers saw the new opportunity and it filled them with enthusiasm. Although in 2018 it was common practice, the speed of the selection was slower than it had been 10 years before. In 2018, its novelty had already worn off and this was the reason why soldiers' enthusiasm also faded.

While in 2008 commander-to-soldier relations were more important than soldierto-soldier relations, in 2018 it was the other way around. Personal relations had a more important role, coming before official interactions. A couple of things may have caused it. 
Relationships between soldiers are stronger as a result of the time they spend together, for example, on CBRN exercises abroad, even working with live chemical agents (travelling abroad with a CBRN subunit was not common in the 2000s), or while serving along and defending the southern border of the country. As a secondary effect, relationships formed off duty, outside the barracks further strengthen this factor. The other side of the coin must also be examined: the decreasing importance of commander-to-soldier relations. How could this be? The answer is very similar to the explanation of the decreased importance of elite consciousness in 2008: something is important when it has a major positive or a negative connotation, something is important when it counts. In 2008 it counted (124) and in 2018 it counted even more (115).

In the course of the survey, just out of curiosity, I decided to ask the sample group one more question: for how much extra money would they consider leaving the army when their contract was about to expire and they gathered information about salaries in the civilian sector? They were also asked to give their age. Figure 1 shows the relationship between salary-motivated outflow and age.

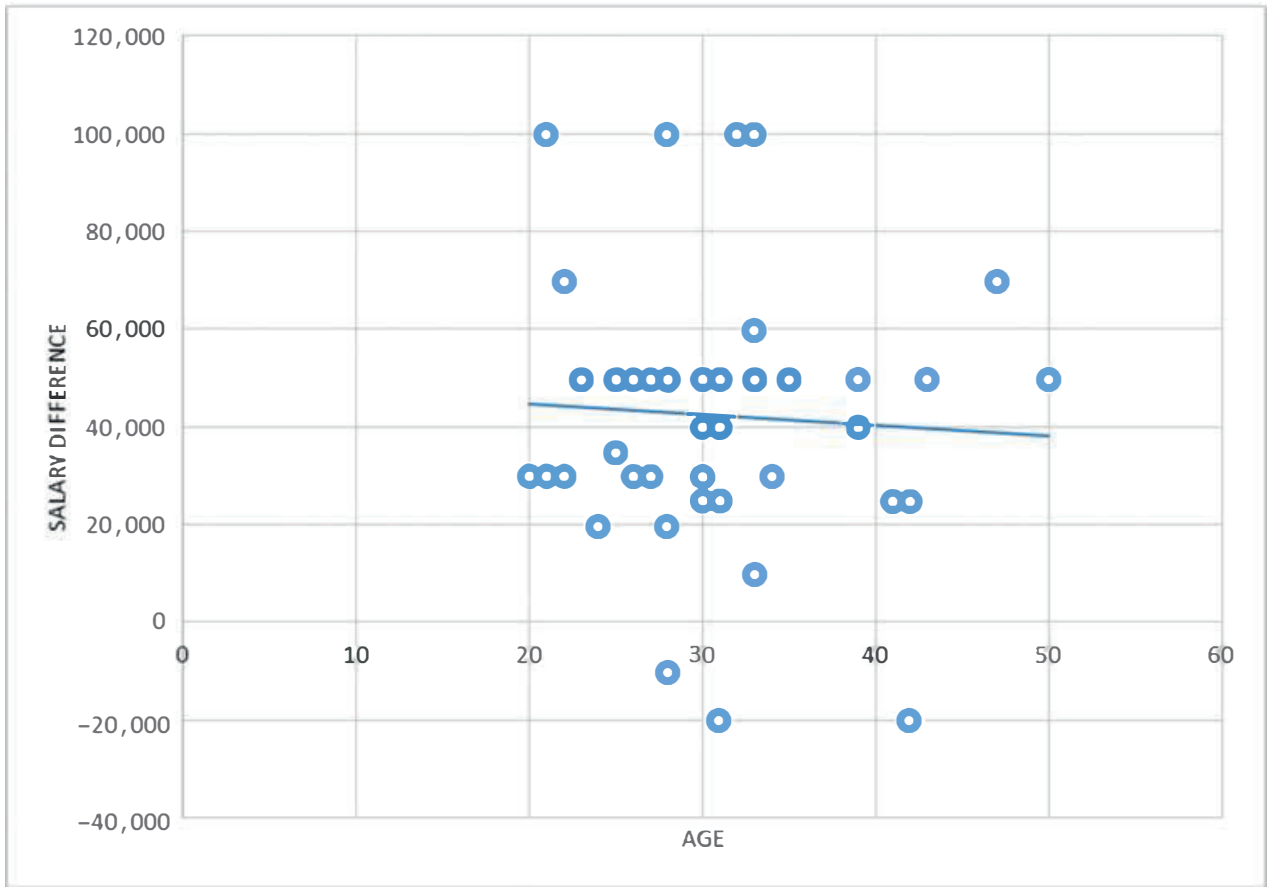

Figure 1: Relationship between salary-motivated outflow and age in the HDF $93^{\text {rd }}$ CBRN Battalion

Source: Compiled by the author.

The figure above shows that 3 out of the 50 soldiers would leave the CBRN battalion even for a lower salary when their contracts expired. Consequently, they did not get from the 
military what they expected. 2 out of these 3, who were not in the youngest age-group, ranked career as number one, so it was obvious that they were disappointed by the lack of predictable career prospects.

Fortunately, most soldiers stay in the CBRN battalion for even less pay than in the civilian sector. Most of the respondents said they would leave the army for an extra 40,000-50,000 Forints and there were a few 'extremists' who would only leave if they were offered 100,000 Forints more than their salary in the army. The average salary increase that would cause leaving the army is slightly decreasing with age but, as it can be seen, the three soldiers over 42 would quit only for a higher than average amount of money. Logically, they are afraid of starting afresh in a new workplace.

\section{Conclusion}

The key amount is 50,000 Forints, which has to be kept in mind. As this survey shows, if in 2018 civilian employers were able to offer a salary 50,000 Forints higher than what a soldier earned in the army, the majority of contract CBRN soldiers would leave.

Those soldiers who do not want to work hard and cannot follow the military regulations usually drop out but those who are suitable for service should not be forced to leave the army because of conditions that can actually be changed.

In conclusion, the main message of this work is that commander-to-soldier relations have a huge effect on soldiers' lives, which cannot be ignored. It is an enormous responsibility for every leader/commander - they are the ones who can do the most for their soldiers. They can influence relations among their subordinates, and they shape the morale of the unit. Their most important task is to find the golden mean between consistency and empathy. When a leader is selected, his/her leadership style should be examined. The commander/leader at any level is responsible for the cohesion of the unit/ subunit and is a role model for the younger officers. Officers who are not able to lead a unit/ subunit by example should not have subordinates.

\section{References}

MH 93. Petőfi Sándor Vegyivédelmi Zászlóalj 2019. évi munkaterve [213/2019 HDF 93 CBRN BN Work Programme for 2019].

MH 93. Petőfi Sándor Vegyivédelmi Zászlóalj Katasztrófavédelmi Alkalmazási Terv [4/853 HDF 93 ${ }^{\text {rd }}$ CBRN BN Disaster Management Response Plan].

Fehér, Katalin, 'Nevelési stílusok', s. a. Online: www.drfeherkatalin.hu/upld/3.pdf

Karácsonyi, András, A leadership, a szervezeti kultúra és kapcsolatuk jellegzetességei a magyar szervezetek esetében. PhD thesis, Corvinus University of Budapest, 2006. Online: http:// phd.lib.uni-corvinus.hu/7/1/karacsonyi_andras.pdf

Travis, Eryn, ‘Fiedler’s Contingency Theory of Leadership’. Bizfluent, 02 November 2018. Online: https://bizfluent.com/info-7756327-fiedlers-contingency-theory-leadership. html 
Attila CSÓKA: Reducing the Outflow of CBRN Soldiers from the Perspective of Motivation

Szombati, Zoltán and László Földi, ‘Az MH 93. Petőfi Sándor Vegyivédelmi Zászlóalj katasztrófa-elhárítási feladatban való részvételének tapasztalatai’. Hadmérnök 6, no 1 (2011), 249-260. Online: http://m.ludita.uni-nke.hu/repozitorium/bitstream/ handle/11410/2029/2011_1_szombati_foldi.pdf?sequence=1\&isAllowed=y 